\title{
Value versus growth: Australian evidence
}

\author{
Philip Gharghori, Sebastian Stryjkowski and Madhu Veeraraghavan*
}

Department of Accounting and Finance, Monash University, Clayton, Victoria 3800, Australia

\section{Corresponding Author}

Philip Gharghori

Department of Accounting and Finance

Monash University

Victoria 3800 Australia

Tel: +61399059247

Fax: +6139905 5475

Email: philip.gharghori@buseco.monash.edu.au

\footnotetext{
* The helpful feedback of participants at the second annual symposium on value investing for the Ben Graham Centre for Value Investing held as part of the 2009 Multinational Finance Society conference and participants at the 2009 Australasian Finance and Banking Conference are gratefully acknowledged. In particular, we are thankful to our symposium discussant, Rob Arnott for helpful comments. We are grateful for the financial assistance provided by the Department of Accounting and Finance at Monash University (1779361). Gharghori and Veeraraghavan are centre associates of the Melbourne Centre of Financial Studies.
} 


\title{
Value versus growth: Australian evidence
}

\begin{abstract}
Fama and French (1992) and Lakonishok, Shleifer and Vishny (1994) show that value stocks earn substantially higher returns than growth stocks. Barbee, Mukherji and Raines (1996) and Leledakis and Davidson (2001) show that the ratio of sales-to-price and debt-to-equity are better predictors of average equity returns than book-to-market equity and firm size. In this paper, we evaluate the ability of book-to-market, sales-to-price, earnings-to-price, cash flow-to-price, debtto-equity and size in explaining equity returns using data drawn from the Australian equities market. Although our results show that sales-to-price, earnings-to-price and cash flow-to-price are significant in explaining cross-sectional variation in equity returns, we conclude that on balance, the book-to-market ratio is the superior value/glamour proxy. Our findings are relevant to both fund managers and individual investors.
\end{abstract}

Key words: value-glamour, book-to-market effect, Fama-French model

EFM Classification: 310,350

JEL Classification: G10, G11, G12, G15 


\section{Introduction}

Value investing can be traced back to Graham and Dodd (1934) who define value firms as those that have poor past performance and are expected to perform poorly in the future while glamour firms as those that have strong past performance and are expected to perform strongly in the future. Athanassakos (2007) states that value investors search for stocks that are neglected and undesirable due to poor performance. Value stocks are associated with firms experiencing difficult times, operating in mature industries or facing adverse circumstances such as a lawsuit or poor subsidiary performance (Brandes, 2006 and Athanassakos, 2007). On the other hand, glamour firms are generally fast growing firms and function in dynamic industries. This divergence in attributes is evident in their valuation metrics.

Graham and Dodd (1934) document that value stocks feature high book-to-market, earnings-to-price or cash flow-to-price ratios while glamour stocks are at the opposite end of the spectrum. Although numerous studies in the last three decades have documented that value stocks - stocks with high ratios of fundamentals to price such as book-to-market (B/M), earnings-to-price $(E / P)$, or cash-flow-to-price $(C / P)$ outperform glamour stocks - stocks with correspondingly low fundamentals-to-price ratios, the jury is still out on whether the value premium anomaly is driven by risk or behavioural factors.

At one extreme is the camp led by Fama and French (1992) who state that beta has little or no ability in explaining equity returns and document that firm size and B/M explain the crosssectional variation in equity returns better than the beta of a security. Fama and French (1996) advance that value strategies outperform growth strategies because they are fundamentally riskier - investors in value stocks (for example investing in high $\mathrm{B} / \mathrm{M}$ ) are compensated for bearing high fundamental risk. In short, they argue that B/M serves as a proxy for risk.

At the other extreme, Lakonishok, Shleifer and Vishny (1994) not only document that firm size and $\mathrm{B} / \mathrm{M}$ are not significant in explaining cross-sectional variation in equity returns once $\mathrm{C} / \mathrm{P}$ and $\mathrm{E} / \mathrm{P}$ are included in the model, but dismiss the risk-based explanation of Fama and French 
(1992) by arguing that value strategies generate superior returns due to investor irrationality. Specifically, they report that value stocks generate superior returns due to expectational errors made by investors. In a similar vein, La Porta (1996) and La Porta, Lakonishok, Shleifer and Vishny (1997) state that value stocks generate superior returns due to behavioural factors and expectational errors made by investors.

Barbee, Mukherji and Raines (1996) document that sales-to-price (S/P) may be a more reliable indicator of a firm's relative market valuation than $\mathrm{B} / \mathrm{M}$ because sales figures are less affected by company specific factors than the book value of equity. Barbee et al. (1996) show that size and $B / M$ are not significant in explaining equity returns once $S / P$ and the debt-to-equity ratio $(D / E)$ are included in the regressions. Similarly, Leledakis and Davidson (2001) show that $\mathrm{S} / \mathrm{P}$ is highly significant in explaining the cross-sectional variation in equity returns in the UK. In Japan, Chan, Hamao and Lakonishok (1991) find that B/M and C/P are significant in explaining returns. These findings add to the growing evidence that alternative measures may be superior to the $\mathrm{B} / \mathrm{M}$ measure proposed by Fama and French (1992). Hence, it is important to evaluate the ability of variables other than size and $\mathrm{B} / \mathrm{M}$ in explaining average equity returns. Given this backdrop, we evaluate the ability of $B / M, S / P, E / P, C / P, D / E$ and firm size in explaining returns for Australian equities.

We study the Australian market for the following reasons. First, the bulk of the existing research relates to the US market and little has been published on the performance of value and growth strategies in the Australian market. To our knowledge, there are only two papers that have employed a cross-sectional regression framework to investigate the performance of firm specific variables in explaining average equity returns (Chan and Faff, 2003 and Gharghori, Chan and Faff, 2009).

Second, the Australian market provides an interesting setting for this type of study because the value/glamour effect has been shown to be stronger in smaller concentrated markets such as Australia. For instance, Fama and French (1998) document that out of thirteen 
major markets, the value/glamour effect was strongest in Australia. Halliwell, Heaney and Sawicki (1999) examine the robustness of the Fama-French model for Australian equities and document that there is significant non-beta risk associated with firm size but find little evidence of a B/M effect in explaining equity returns. Gaunt (2004) reports that the Fama-French model explains returns better than the CAPM and that the B/M factor plays an important role in asset pricing. More recent evidence by Gharghori, Chan and Faff (2006, 2007 and 2009) finds strong evidence of a B/M effect in Australia.

Third, the Australian market is unique because it is highly concentrated with around 2,000 listed companies. Although this is comparable to other exchanges, the Australian market is confined to a small number of industries, namely financials and materials (dominated by mining and resources firms). The large number of firms operating in the mining and resources sector introduces a number of challenges when examining firm specific variables based on sales, earnings and cash flows. A large number of firms involved in mining and resources report earnings and cash flows that are zero or negative in their profit and loss statements during their early years of operation. Given that a large number of firms have negative earnings and cash flows, we investigate the relationship between negative $\mathrm{E} / \mathrm{P}$ and $\mathrm{C} / \mathrm{P}$ with returns. In addition, we include size and D/E as control variables because of their well documented association with returns (Banz, 1981 and Bhandari, 1988).

Our paper is closely related to Chan et al. (1991), Lakonishok et al. (1994), Barbee et al. (1996), Cai (1997) and Leledakis and Davidson (2001) as the variables employed in this paper are primarily chosen because they encompass almost all of the variables investigated in the aforementioned papers ${ }^{1}$. For example, Chan et al. (1991) investigate the relationship between returns on Japanese stocks and B/M, E/P, C/P and firm size. Lakonishok et al. (1994)

\footnotetext{
${ }^{1}$ The one variable from these papers that we do not consider is past sales growth. The main reason for this is that past sales growth is calculated using a time-series of sales values and as a result, including this variable would severely compromise our sample size. Additionally, none of the studies that consider past sales growth find that it is the dominant variable in their analysis.
} 
investigate the relationship between returns on US stocks and $B / M, E / P, C / P$ and past growth in sales. Barbee et al. (1996) investigate the relationship between returns on US stocks and B/M, D/E, S/P and firm size. Cai (1997) investigates the relationship between returns on Japanese stocks and B/M, C/P, E/P and sales rank and Leledakis and Davidson (2001) evaluate the relationship between returns on UK stocks and $B / M, S / P, D / E$ and firm size. Our work differs from the aforementioned papers as we not only employ the three empirical proxies (B/M, E/P and $C / P$ ) traditionally used in the literature but also investigate the explanatory power of $S / P$, D/E and firm size.

Although there is no consensus in the prior literature on the choice of firm characteristics, the traditional value-glamour proxies employed in this paper $(B / M, C / P$ and $E / P)$ have been successfully used in Chan et al. (1991), Lakonishok et al. (1994) and Cai (1997). In addition, Lamont (1998) states that earnings contain information about future returns that is not captured by other variables. Specifically, Lamont (1998) states that the level of earnings is a good measure of current business conditions and as earnings vary with economic activity, current earnings predict future returns. In a similar vein, Campbell and Yogo (2006) also document stronger predictive evidence from E/P than from the dividend yield. A natural question to ask is why S/P and D/E? We include S/P and D/E as Barbee et al. (1996) document that these two variables have greater explanatory power than firm size and $\mathrm{B} / \mathrm{M}$ ratio in explaining US stock returns. In addition, Bhandari (1988) documents that the expected returns on common stocks are positively related to the debt/equity ratio after controlling for beta and firm size. Thus, we include $\mathrm{S} / \mathrm{P}, \mathrm{D} / \mathrm{E}$ and firm size to determine the variable(s) that best identifies value/glamour firms and predicts equity returns in Australia.

Our findings can be summarised as follows. Consistent with Fama and French (1998), we find evidence of a value premium in Australia when we sort portfolios on $B / M, S / P, E / P$, and $\mathrm{C} / \mathrm{P}$. Our analysis reveals that all of these variables are individually significant in explaining the cross-sectional variation in equity returns. In regressions on multiple variable models, we find 
that on balance, $B / M$ is the superior proxy. Although $S / P, E / P$ and $C / P$ are significant, only 75 percent of our sample had recorded sales in their financial statements and only 55 percent of firms recorded positive values of earnings and cash flows. To account for this, we propose a modelling technique that allows us to incorporate firms with zero sales, and firms with both positive and negative $\mathrm{E} / \mathrm{P}$ (and $\mathrm{C} / \mathrm{P}$ ) into the analysis. In contrast to $\mathrm{S} / \mathrm{P}, \mathrm{E} / \mathrm{P}$ and $\mathrm{C} / \mathrm{P}, 95$ percent of all firms in the sample had positive book values. This makes it possible to calculate the $\mathrm{B} / \mathrm{M}$ ratio for the majority of firms in our sample without having to resort to additional modelling approaches to incorporate negative $\mathrm{B} / \mathrm{M}$ firms into the analysis.

Our study contributes to the existing literature in two ways. First, we contribute to the limited Australian literature on the value/glamour effect and provide evidence that supports the existence of an effect in Australia. Second, we identify the firm specific variables that best identify value/glamour firms in Australia. To our knowledge, no published research has examined the value/glamour effect in Australia. Prior studies have only examined B/M as a proxy for value/glamour (see, Chan and Faff, 2003 and Gharghori et al., 2009). Our findings are relevant to investment managers as value and glamour strategies are widely in industry. The remainder of this paper is organised as follows. Section 2 describes the data and the methods employed in this paper. Section 3 presents the empirical findings and Section 4 concludes the paper.

\section{Data and methods}

\subsection{Data}

Our empirical analysis is performed at the monthly level for the period January 1993 to December 2004. The data come from two sources. The monthly share price data and market capitalisation are sourced from the Centre for Research in Finance (CRIF) database. Data for total assets, intangibles, total equity, total liabilities, sales, net profit after tax before abnormals and net cash flows from operations are obtained from Aspect Huntley. The full sample is the 
intersection of the Aspect Huntley and CRIF databases and is limited to the number of firms for which accounting data is available. The matching process between the databases was quite successful as only one percent of firm-year observations in the Aspect Huntley database were not matched with corresponding price data from the CRIF database. We define book equity as net tangible assets, sales as trading revenue, cash flow as net cash flow from operations, earnings as net profit after tax before abnormals, size as market value of equity and debt as book value of $\mathrm{debt}^{2}$. In calculating the ratios, there is no time lag implemented between the accounting and price data. This is done following Chan and Faff (2003) and Gharghori et al. (2009). Returns are realised monthly returns measured one month after $B / M, S / P, E / P, C / P, D / E$ and firm size are measured.

We employ four filters to ensure the accuracy of the accounting data. First, we check that Assets - Liabilities - Equity $=0$. Second, we verify that Net Cash Flow from Operations + Net Cash Flow from Investing + Net Cash Flow from Financing - Net Increase in Cash Held $=0$. Third, we test whether Profit Before Tax and Abnormals + Tax Expense - Net Profit After Tax Before Abnormals $=0$. Lastly, we verify that Total revenue - Trading revenue - Other revenue $=$ 0 . Firms that fail to meet these filters are excluded from the final sample.

Our filters eliminated 12,818 observations (approximately 9 percent of the initial sample). This number includes firms with negative book values (approximately 5 percent of the sample) and firms that failed to meet our accounting data filters (a further 4 percent of the initial sample). Our final sample has 137,139 firm-month observations. We replicated the analysis and included negative book equity firms and our inferences do not change. A large proportion of our sample firms recorded negative earnings and negative cash flows (43 percent of firm month observations contain negative earnings while 45 percent recorded negative cash flows). We

\footnotetext{
${ }^{2}$ In contrast to Barbee et al. (1996) and Leledakis and Davidson (2001), we define debt in D/E as total liabilities. There are two reasons for this. First, to remain consistent with prior research by Gharghori et al. (2007 and 2009) and second, it is difficult to infer the reliability of book value of common equity using filters.
} 
were initially surprised by the large proportion of firms that reported negative earnings or cash flows. To investigate this further, we manually checked hard copy annual reports for a sample of the firms that reported negative earnings. Further, we also checked company announcements obtained from SIRCA to see if the announced earnings were consistent with the annual reports. The hardcopy annual reports and company announcements confirmed the values obtained from the Aspect Huntley database. A sizable proportion of firms (26 percent of all firm-month observations) did not record any sales data. We include firm month observations for which no sales data exists in our regressions by assuming a sales figure of zero. We also repeated the analysis omitting the firm-month observations without sales data and our conclusions remain unchanged. Nevertheless, that 26 percent of the sample has a sales value of zero is a weakness of S/P as a proxy for value/glamour. This is because for this proportion of the sample, there can be no cross-sectional variation between S/P and returns. A large proportion of the firms that recorded no sales or negative earnings or cash flows are resource companies. This is to be expected because many of the listed mining and resources companies do not generate any trading revenue in their early years of operation and thus have negative earnings and cash flows, and no sales.

\subsection{Methods}

We rely primarily on two methodologies in our analysis of the relationship between firm specific variables and average equity returns: (1) a portfolio analysis approach, in which portfolios are formed on a chosen variable and the relationship with average returns is investigated, and (2) a cross-sectional regression approach, which is based on individual firms rather than portfolios.

\subsubsection{Portfolio analysis}

The portfolio analysis procedure used is similar to that of Fama and French (1992) and Leledakis and Davidson (2001) in which portfolios are formed every month by placing firms into 
deciles, based on rankings on each of the six variables chosen for this study. Decile 1 represents firms with the lowest value of the sorting variable while decile 10 has firms with the highest value. Each month, the equally weighted average return of each decile is calculated. This procedure allows identification of any relationships between the sorting variable and the subsequent returns on the portfolios formed.

A large proportion of firms in the sample recorded negative values for earnings and cash flows. Negative values of $E / P$ and $C / P$ are considered separately by placing the firms into quintiles instead of deciles. For E/P, we split stocks into positive and negative earnings groups and then subdivide each group into five portfolios. A similar procedure is implemented for $\mathrm{C} / \mathrm{P}$ based on positive and negative cash flows. We analyse the positive and negative earnings (cash flow) sub-samples separately because it is possible that the relationship between E/P $(C / P)$ and returns differs depending on whether earnings (cash flows) are positive or negative. In part, this expectation is based on the risk-based argument that Fama and French (1996) propose to explain the value-glamour effect, which implies a different relationship between both $E / P$ and $\mathrm{C} / \mathrm{P}$ with returns depending on whether earnings (cash flows) are positive or negative. For positive earnings or cash flows, high E/P and C/P stocks (value stocks) should outperform low $\mathrm{E} / \mathrm{P}$ and $\mathrm{C} / \mathrm{P}$ stocks (growth stocks) because they are more risky. That is, there should be a positive relationship between $\mathrm{E} / \mathrm{P}$ and $\mathrm{C} / \mathrm{P}$ with returns. However, for negative earnings or cash flows the opposite is expected. The reason is that very negative $\mathrm{E} / \mathrm{P}$ or $\mathrm{C} / \mathrm{P}$ stocks are perceived by the market to be more risky than slightly negative E/P or C/P stocks. Thus, the stock price of very negative $\mathrm{E} / \mathrm{P}$ or $\mathrm{C} / \mathrm{P}$ stocks is bid down further than the price of slightly negative $\mathrm{E} / \mathrm{P}$ or $\mathrm{C} / \mathrm{P}$ stocks to reflect an expectation of higher risk, which should be subsequently rewarded with a higher return. Therefore, for the negative sub-samples, very negative E/P or C/P stocks should outperform slightly negative E/P or C/P stocks. Given the above, we expect the average returns for the most negative $E / P$ and $C / P$ firms $(Q 1)$ to be higher than the average returns for the least negative E/P and C/P firms (Q5). 
In addition, the behavioural argument of Lakonishok et al. (1994) also predicts a nonlinear relationship between $E / P(C / P)$ with returns depending on whether earnings (cash flows) are positive or negative. First, let us consider the positive earnings or cash flow case. Lakonishok et al. (1994) argue that investors under (over) extrapolate the performance of value (growth) firms and that this is the cause of the higher (lower) returns of these firms in the future. In the same way that the risk-based argument of Fama and French (1996) can be applied to firms with negative earnings and cash flows, the behavioural argument of Lakonishok et al. (1994) can also be applied to this subset of firms. For firms with very negative E/P or C/P, investors under extrapolate the performance of these firms and bid down the stock price (relative to less negative $\mathrm{E} / \mathrm{P}$ or $\mathrm{C} / \mathrm{P}$ firms) resulting in higher future returns once the expectational errors are corrected. Conversely, investors over extrapolate the performance of firms with less negative $\mathrm{E} / \mathrm{P}$ or $\mathrm{C} / \mathrm{P}$ and bid up the stock price (compared with more negative $\mathrm{E} / \mathrm{P}$ or $\mathrm{C} / \mathrm{P}$ firms), which results in lower future returns when the expectational errors are corrected. Thus, we contend to both a risk-based and a behavioural argument to predict a non-linear relationship between E/P $(\mathrm{C} / \mathrm{P})$ and returns depending on whether earnings (cash flows) are positive or negative.

\subsubsection{Regression analysis}

A cross-sectional framework is employed to identify which variables are significant in regressions at the individual firm level. In the cross-sectional regression analysis, the general framework of Fama and MacBeth (1973) is used to remain consistent with Fama and French (1992) and Leledakis and Davidson (2001). This approach involves cross-sectional regressions of next month's stock returns on the firm specific variables for each month of the sample period.

Following, Chan and Faff (2003) and Gharghori et al. (2009), our cross-sectional regressions are estimated using Ordinary Least Squares adjusted for White's (1980) heteroskedasticity consistent covariance matrix and Weighted Least Squares is employed to infer the sign and significance of the time series of cross-sectional regression parameters. The 
focus of the regression analysis is to investigate the individual and joint explanatory power of the six variables in explaining equity returns. Different variations of the regression model specified below are estimated:

$$
\mathrm{R}_{\mathrm{i}}=\gamma_{0}+\gamma_{1} \frac{\mathrm{B}}{\mathrm{M}}+\gamma_{2} \frac{\mathrm{S}}{\mathrm{P}}+\gamma_{3} \frac{\mathrm{E}}{\mathrm{P}}+\gamma_{4} \frac{\mathrm{C}}{\mathrm{P}}+\gamma_{5} \frac{\mathrm{D}}{\mathrm{E}}+\gamma_{6} \ln (\mathrm{SIZE})+\varepsilon_{\mathrm{i}}
$$

Consistent with the portfolio returns analysis, we analyse the relationship between positive and negative E/P (C/P) and returns separately. To do so, we split E/P into two separate variables (or two interaction terms for the E/P variable) when conducting the Fama-MacBeth regressions. One of the interaction terms for the $E / P$ variable includes the positive values of $E / P$ and zeros in place of the negative E/P observations. The other includes the negative values of $\mathrm{E} / \mathrm{P}$ and zeros instead of the positive $\mathrm{E} / \mathrm{P}$ values. The advantage of employing interaction terms for positive and negative E/P values is that allows for asymmetry in the relationship between E/P and returns. The same approach is employed for positive and negative values of $\mathrm{C} / \mathrm{P}$. Following Jaffe, Keim and Westerfield (1989), Chan et al. (1991), Lakonishok et al. (1994) and Dichev (1998), we take the natural logarithm of size but we do not take the logarithm of the ratios. The reason we do not take the logarithm of the ratios is due to the large number of zero observations for $\mathrm{S} / \mathrm{P}$ and for the $\mathrm{E} / \mathrm{P}$ and $\mathrm{C} / \mathrm{P}$ interaction terms.

\section{Results}

\subsection{Preliminaries}

The results of the portfolio analysis are presented in Table 1. Table 1 shows average monthly returns and firm characteristics for the period January 1993 to December 2004 for portfolios formed on book-to-market $(B / M)$, sales-to-price $(S / P)$, debt-to-equity $(D / E)$, firm size, positive earnings-to-price $\left(E / P_{+}\right)$, negative earnings-to-price $\left(E / P_{-}\right)$, positive cash flow-to-price $\left(C / P_{+}\right)$ and negative cash flow-to-price (C/P-).

\section{[Insert Table 1 about here]}


Panel A of Table 1 presents the results of sorting on B/M. Panel A shows a strong positive relation between $\mathrm{B} / \mathrm{M}$ and returns. In Panel $\mathrm{B}$, we document a positive relationship between S/P and average returns. This finding is consistent with Leledakis and Davidson (2001) and Barbee et al. (1996). However, the spread is smaller than the difference between the smallest and largest $\mathrm{B} / \mathrm{M}$ portfolios and similar to $\mathrm{B} / \mathrm{M}$, the relationship between average returns and $S / P$ is not linear. Panel $C$ shows that average returns are generally increasing with leverage; however, the relationship between leverage and returns is not linear and the magnitude of the return differential is not as dramatic as that of the portfolios formed on the variables that identify value/glamour firms. Panel $\mathrm{D}$ shows that the relationship between average returns and size is negative, consistent with Banz (1981). Once again, we observe that the relationship is non-linear. The two lowest deciles contain abnormally high monthly returns. When we exclude the two smallest deciles and focus on deciles three to ten, we find little variation in average returns. These results suggest that the well documented size effect appears to be driven by the smallest firms. This finding is consistent with Chan and Faff (2003) and Gharghori et al. (2009). Panel E reports the average returns for portfolios formed on positive and negative $\mathrm{E} / \mathrm{P}$. We find a positive relationship between average returns and $\mathrm{E} / \mathrm{P}+$, which is consistent with Chan et al. (1991) and Lakonishok et al. (1994). As far as negative E/P firms are concerned, we find a negative relationship between average returns and E/P-. This finding supports our conjecture that the concept of value/glamour can be applied to the subset of firms with negative earnings. Similar to the findings on E/P, Panel $F$ shows a positive (negative) relationship between positive (negative) $\mathrm{C} / \mathrm{P}$ and returns. The positive relation between positive $\mathrm{C} / \mathrm{P}$ and returns is consistent with Chan et al. (1991) and Lakonishok et al. (1994). The negative relation between negative $\mathrm{C} / \mathrm{P}$ and returns (as with negative $\mathrm{E} / \mathrm{P}$ and returns) is a new finding that we do not believe has been reported before. Further, it is consistent with our claim that the notion of value/glamour can be applied to firms with negative cash flows. In summary, the analysis provides evidence that value strategies outperform growth strategies. A leverage effect is also 
apparent and the well documented size effect appears to be present, however, only the smallest firms produce large average returns.

A few brief comments on the interrelationships between the firm characteristics are worth making. In Panels $A, B$ and $C$, we observe that $B / M, S / P$ and $D / E$ are positively related. In Panel $A(B / M)$ and $C(D / E)$, we see that the mean $E / P$ of all portfolios is negative. Panel $D$ shows that all of our value/glamour proxies are related to size; $\mathrm{B} / \mathrm{M}$ and $\mathrm{S} / \mathrm{P}$ decrease, and $\mathrm{E} / \mathrm{P}$ and $\mathrm{C} / \mathrm{P}$ increase as size increases. This justifies our inclusion of size as a control variable in the regression analysis. Panels $E$ and $F$ both show that the relationship between the firm characteristics differs depending on whether $E / P$ and $C / P$ are positive or negative, consistent with our conjecture that the positive and negative sub-samples need to be examined separately. For the negative sub-sample, $\mathrm{B} / \mathrm{M}, \mathrm{S} / \mathrm{P}$ and $\mathrm{D} / \mathrm{E}$ decrease, and size increases as $\mathrm{E} / \mathrm{P}$ and $\mathrm{C} / \mathrm{P}$ increase. Conversely, for the positive sub-sample, B/M, S/P and D/E increase as E/P and C/P increase. Throughout all panels, we observe a relationship between D/E and the value-glamour proxies, which justifies its inclusion in the subsequent analysis. Finally, we note from Panels $\mathrm{E}$ and $\mathrm{F}$ that firms that report negative earnings or cash flows are much smaller than firms that report positive earnings or cash flows, which provides further support for including size as a control variable.

To investigate the relationship between all six variables further, we produce a correlation matrix for the variables. Table 2 presents the time series average of the monthly Spearman rank correlations between all six variables. The Spearman rank correlation method is preferred to Pearson correlations because it is a nonparametric test. To interpret the sign, magnitude and significance of a Pearson correlation validly, the distribution of each variable must be Gaussian, which clearly cannot be the case with the S/P variable and the E/P and C/P interaction terms where a large proportion of the observations are zeroes.

[Insert Table 2 about here] 
Panel A of Table 2 presents the correlations for the full sample. If the four ratios chosen are reliable measures of value/glamour, we should observe positive correlations between B/M, $\mathrm{S} / \mathrm{P}, \mathrm{E} / \mathrm{P}+$ and $\mathrm{C} / \mathrm{P}+$. Additionally, $\mathrm{E} / \mathrm{P}$ - and $\mathrm{C} / \mathrm{P}$ - should have a negative correlation with $\mathrm{B} / \mathrm{M}$ and $S / P$, and a positive correlation with each other. Panel $A$ shows that this is the case with the exception of the correlations between S/P and both E/P- and C/P-. For further insight, Panels B and $\mathrm{C}$ present the correlations on the positive and negative E/P sub-samples, respectively. In Panel C, we see that the correlation between S/P and E/P- is now negative but S/P's correlation with $\mathrm{C} / \mathrm{P}$ - remains positive, which is inconsistent with our expectation. Table 2 shows that there are a number of high correlations, which could have implications for the regression analysis. Notably, the correlation between $S / P$ and $D / E$ in all three panels is quite high. In Panel $A$, we observe very high correlations between $\mathrm{E} / \mathrm{P}_{+}$and $\mathrm{E} / \mathrm{P}$ - and similarly between $\mathrm{C} / \mathrm{P}_{+}$and $\mathrm{C} / \mathrm{P}_{-}$, Panels $B$ and $C$ present similar findings for the $C / P$ interaction terms. The correlations between $\mathrm{E} / \mathrm{P}+$ and $\mathrm{E} / \mathrm{P}-$, and between $\mathrm{C} / \mathrm{P}+$ and $\mathrm{C} / \mathrm{P}$ - are artificial correlations that arise from the creation of the interaction terms for $\mathrm{E} / \mathrm{P}$ and $\mathrm{C} / \mathrm{P}$. The correlations are artificial in the sense that they do not truly exist but have arisen solely from splitting $E / P(C / P)$ into two interaction terms based whether earnings (cash flows) are positive or negative. Nevertheless, the high artificial correlations between each pair of interaction terms could lead to a multicollinearity problem in the regression analysis.

\subsection{Regression analysis}

\subsubsection{Regressions of each variable in isolation}

Panel A of Table 3 presents the results of Fama-MacBeth regressions of each variable in isolation on the full sample. All of the value/glamour proxies are significantly related to returns and the signs of the average parameter estimates are consistent with expectations. $B / M, S / P$, $\mathrm{E} / \mathrm{P}+$ and $\mathrm{C} / \mathrm{P}+$ are significantly positively related to returns, and $\mathrm{E} / \mathrm{P}$ - and $\mathrm{C} / \mathrm{P}$ - are significantly negatively related to returns. These results are consistent with the portfolio returns analysis 
conducted earlier. Thus, our findings indicate that all four value/glamour proxies employed are reliable proxies for value/glamour and that value firms outperform glamour firms. In addition, it is comforting to observe that both interaction terms for $\mathrm{E} / \mathrm{P}$ and $\mathrm{C} / \mathrm{P}$ are significant and of the expected sign, particularly since Table 2 shows that the artificial correlation between each pair of interaction terms is very high. As further confirmatory evidence of the non-linear relationship between $\mathrm{E} / \mathrm{P}$ and $\mathrm{C} / \mathrm{P}$ with returns, Panels $\mathrm{B}$ and $\mathrm{C}$ present the regression output on the positive and negative earnings sub-samples, respectively. The results are consistent with the full sample analysis in Panel $A$ in that the average parameter estimates on $E / P_{+}\left(E / P_{-}\right)$and $C / P_{+}\left(C / P_{-}\right)$are significantly positive (negative) for the positive (negative) earnings sub-sample. Finally, Panel $A$ shows that $\mathrm{D} / \mathrm{E}$ is significantly positively related to returns and that size is not significant. It is not surprising to find that size is insignificant as the portfolio returns analysis in Table 1 shows that the relationship between size and returns is non-linear.

\section{[Insert Table 3 about here]}

\subsubsection{Regressions of multiple variable models}

In the portfolio returns analysis and the Fama-MacBeth regressions of each variable in isolation, we observe that each value/glamour proxy is related to returns and that the direction of the relationships is consistent with each variable being a reliable proxy for value/glamour. However, as we have chosen each variable because we believe it is a reliable proxy for value/glamour, we also expect that the variables will be correlated. In addition, as each of our value/glamour proxies is a ratio that is scaled by share price, this also suggests that the variables will be correlated. In Table 2, we observe that in almost all cases, the sign of the correlations between the value/glamour proxies are consistent with expectations and that some correlations are quite high. One of the aims of this paper is to identify the best proxy of value/glamour. In order to do so, it is necessary to perform regressions on multiple variable models to identify which variable is superior, particularly as the proxies are interrelated. Table 4 presents the results of these regressions. 


\section{[Insert Table 4 about here]}

Panel A of Table 4 presents the output of regressions on the full sample. The first regression reported in Panel $\mathrm{A}$ is of all four value/glamour proxies. $\mathrm{B} / \mathrm{M}, \mathrm{S} / \mathrm{P}, \mathrm{E} / \mathrm{P}+$ and $\mathrm{C} / \mathrm{P}+$ are significantly positively related to returns, whereas E/P- and C/P- are insignificant. The second regression reported in Panel $A$ is on all six variables (the four value/glamour proxies, and D/E and size). We have chosen to include D/E and size in the analysis as prior research has shown that both variables explain cross-sectional variation in returns. As with the regression on the four value/glamour proxies, the average coefficients on $B / M, S / P, E / P+$ and $C / P+$ are significant and positive whereas $\mathrm{E} / \mathrm{P}$ - and $\mathrm{C} / \mathrm{P}$ - are insignificant. Thus, the inferences drawn from the regression on all four value/glamour proxies are robust to the inclusion of $D / E$ and size. Although the coefficients on the positive $\mathrm{E} / \mathrm{P}$ and $\mathrm{C} / \mathrm{P}$ interaction terms are significant, the insignificant coefficients on the negative $\mathrm{E} / \mathrm{P}$ and $\mathrm{C} / \mathrm{P}$ interaction terms suggest that neither $\mathrm{E} / \mathrm{P}$ nor $\mathrm{C} / \mathrm{P}$ are the superior proxy for value/glamour. This leaves $B / M$ and $S / P$. In the regression on all four value/glamour proxies, the $t$-statistic for $\mathrm{S} / \mathrm{P}$ is higher than for $\mathrm{B} / \mathrm{M}$ (2.14 versus 2.04). However, in the regression on all six variables, the t-statistic for $B / M$ is higher (3.41 versus 2.36 ). Thus, further evidence is required to ascertain which value/glamour proxy is superior.

Prior to any further investigation on which of $\mathrm{B} / \mathrm{M}$ or $\mathrm{S} / \mathrm{P}$ is the superior value/glamour proxy, it is pertinent to investigate the insignificant coefficients on E/P- and C/P-in more detail. In Table 3, we observe that E/P- (C/P-) is significant when regressed with $E / P+(C / P+)$. Thus, despite the high artificial correlation between the interaction terms, it is unlikely that the positive $\mathrm{E} / \mathrm{P}$ and $\mathrm{C} / \mathrm{P}$ interaction terms are causing the insignificance of the negative interaction terms in the multiple variable models. An analysis of the correlations in Table 2 shows that with the exception of the artificial correlations between the interaction terms (i.e. between E/P+and E/P-, and $\mathrm{C} / \mathrm{P}+$ and $\mathrm{C} / \mathrm{P}-)$, the highest correlation between $\mathrm{E} / \mathrm{P}$ - is with $\mathrm{C} / \mathrm{P}-$, and vice versa. This is expected, as of the four value/glamour proxies, E/P and C/P are the most closely related. There are two reasons for this. First, recall that roughly 45 percent of the sample observations have 
negative earnings or cash flows, and second, the measurement of earnings and cash flows is similar, particularly in comparison to book equity and sales. Thus, it may be that the inclusion of $\mathrm{E} / \mathrm{P}$ - and $\mathrm{C} / \mathrm{P}$ - in the same model is causing the insignificance of both variables. To investigate this contention, we reran the regressions in Panel A of Table 4 and in each case, we dropped either $\mathrm{E} / \mathrm{P}$ - or $\mathrm{C} / \mathrm{P}$ - from the regression. Unreported results show that $\mathrm{E} / \mathrm{P}$ - and $\mathrm{C} / \mathrm{P}$ - remain insignificant when the other interaction term is removed from the model. Thus, we are more confident in the robustness of this finding and that $\mathrm{E} / \mathrm{P}$ and $\mathrm{C} / \mathrm{P}$ are not the superior proxies of value/glamour.

Despite the evidence indicating that $E / P$ and $C / P$ are inferior to $B / M$ and $S / P$ as value/glamour proxies, we still feel it is important to investigate the positive and negative earnings sub-samples separately. Although prior research by Jaffe et al. (1989), Chan et al. (1991) and Fama and French (1992) has examined the relationship between negative earnings and returns, to our knowledge, we are the first to apply the concept of value/glamour to negative earnings (and cash flow) firms and to predict a non-linear relationship between E/P and C/P with returns. The observed non-linearities, consistent with expectations, are one of the key contributions of the paper. Further, analysing the positive and negative earnings sub-samples separately may provide insight into whether $\mathrm{B} / \mathrm{M}$ or $\mathrm{S} / \mathrm{P}$ is the superior value/glamour proxy.

Panel B of Table 4 presents the output of regressions on the positive earnings subsample. The first regression reported on all four value/glamour proxies shows that $\mathrm{B} / \mathrm{M}$ and $\mathrm{S} / \mathrm{P}$ are insignificant and that $E / P+$ and $C / P+$ are significant. In the regression with all variables (including $\mathrm{D} / \mathrm{E}$ and size), only $\mathrm{C} / \mathrm{P}+$ is significant. The insignificance of $\mathrm{B} / \mathrm{M}$ and $\mathrm{S} / \mathrm{P}$ for the positive earnings sub-sample is in stark contrast to the full sample results and thus provides moderating evidence to the contention that $\mathrm{B} / \mathrm{M}$ and $\mathrm{S} / \mathrm{P}$ are the superior value/glamour proxies. In fact, for the positive earnings sub-sample, $\mathrm{C} / \mathrm{P}$ is the superior proxy.

In Panel $\mathrm{C}$ of Table 4, counterpart regression results are reported for the negative earnings sub-sample. Of the four value/glamour proxies (B/M, S/P, E/P- and C/P-), only B/M is 
significant. This result holds true for both the regression on the four value/glamour proxies and for the regression on all six variables. In the regression with all variables, the average coefficient on size is significantly negative, indicating that for firms that report negative earnings, there is a negative relationship between size and returns. The insignificant coefficients on E/P- and C/Pprovide confirmatory evidence on the full sample results in Panel A where these interaction terms were also insignificant. Thus, it is clear that after controlling for $B / M$ and $S / P$, the relationship between both E/P- and C/P- with returns is not significant. In sum, for the negative earnings sub-sample, B/M emerges as the best value/glamour proxy. ${ }^{3}$

On balance, we conclude that of the four proxies examined, $B / M$ is the best proxy for value/glamour. There are two reasons we have reached this conclusion. First, the regressions of the multiple variable models on the full sample and on the negative earnings sub-sample show that $\mathrm{B} / \mathrm{M}$ is the most significant variable. Admittedly, in the full sample regression on the four value/glamour proxies, $\mathrm{S} / \mathrm{P}$ has a slightly higher t-statistic, but in the regression on all six variables, $\mathrm{B} / \mathrm{M}$ has the higher $\mathrm{t}$-statistic. Further, $\mathrm{B} / \mathrm{M}$ is the only significant value/glamour proxy in the negative earnings sub-sample. The inference from the regression analysis has to be down-weighted though because for the positive earnings sub-sample, $B / M$ is not significant. Notwithstanding, this is an interesting result as it shows that there are some nuances in our findings based on whether we analyse firms that report earnings across the full spectrum or whether we analyse the positive and negative earnings firms separately. Additionally, this lends weight to the argument that the positive and negative earnings sub-samples should be examined independently. The second reason we conclude that $B / M$ is the superior value/glamour proxy is that $\mathrm{B} / \mathrm{M}$ is positive for 95 percent of the sample, making it possible to measure $\mathrm{B} / \mathrm{M}$ for the vast majority of the sample without having to resort to interaction terms to

\footnotetext{
${ }^{3}$ Brown, Keim, Kleidon and Marsh (1983) present evidence of seasonalities in Australian stock returns. To examine whether our findings are robust to seasonality, we redid the analysis for the months of January and July, and for all months except for January and July. Unreported results, which are available on request from the authors, show that our findings are robust to seasonality.
} 
incorporate negative B/M firms into the analysis. ${ }^{4}$ In contrast, approximately 25 percent of S/P observations are zero and approximately 45 percent of $\mathrm{E} / \mathrm{P}$ and $\mathrm{C} / \mathrm{P}$ observations are negative. Although we have demonstrated how zero values for S/P and negative values for $E / P$ and $C / P$ can be incorporated into the analysis, it is simpler and more parsimonious to not resort to these techniques when measuring value/glamour.

When analysed in isolation, each variable exhibits a relationship with returns that is consistent with prior research. The exceptions being E/P- and C/P-, which to our knowledge have not been examined before. In an Australian context, the relationship between both B/M and size with returns is consistent with recent Australian research by Chan and Faff (2003) and Gharghori et al. (2009). However, the analysis of the multiple variable models does provide some conflicting findings with similar international research. The five studies that are most closely linked to our paper are by Chan et al. (1991), Lakonishok et al. (1994), Barbee et al. (1996), Cai (1997) and Leledakis and Davidson (2001). In fact, the six variables employed in this analysis are primarily chosen because they encompass almost all of the variables in the aforementioned papers (with the exception of past sales growth). Barbee et al. (1996) and Leledakis and Davidson (2001) conclude that S/P is the dominant variable. Cai's (1997) findings support B/M. Chan et al. (1991) find in favour of B/M and C/P, whereas Lakonishok et al.'s (1994) results support E/P and C/P. In our analysis, we conclude that $B / M$ is superior. There are a number of reasons why our findings may differ from prior research. First, this study is an out of sample test in terms of both the market and the time period analysed. Second, we employ Weighted Least Squares to infer the sign and significance of the time series regression parameters, which Chan and Faff (2003) show is superior to the simple average method that the five international studies use. Third, we model and incorporate negative $E / P$ and $C / P$ into the analysis. Fourth, we use a broader range of variables in our analysis. We are confident that our

\footnotetext{
${ }^{4}$ We replicated the analysis and included negative $\mathrm{B} / \mathrm{M}$ firms and our inferences do not change, results are available on request from the authors. Further, Gharghori et al. (2009) have already examined the relationship between both positive and negative B/M with returns in Australia.
} 
inferences are robust to the differing findings of the five international studies, particularly because we believe that the second, third and fourth reasons why our results may differ (specified above) give our paper a competitive advantage over the aforementioned studies.

\section{Summary and conclusions}

Fama and French (1992) find that characteristics that can identify value and glamour firms such as the book-to-market ratio explain the cross-sectional variation in average equity returns better than the beta of a security. This finding led to the Fama and French (1993) three-factor model, which incorporates $\mathrm{B} / \mathrm{M}$ as one the factors that explains cross-sectional variation in equity returns.

Barbee et al. (1996) and Leledakis and Davidson (2001) suggest that other variables may exist that identify value/glamour firms and better predict average equity returns. Specifically, they show that the ratio of sales-to-price is superior to $\mathrm{B} / \mathrm{M}$ in explaining the cross-sectional variation in equity returns. Other studies critical of Fama and French (1992) contend that the findings of Fama and French (1992) are due to data snooping and that the explanatory power of $\mathrm{B} / \mathrm{M}$ is sample specific. The primary aim of this paper is to test these contentions by providing a comprehensive evaluation of possible value/glamour proxies namely, B/M, S/P, E/P and C/P. Hence, our study has two main objectives. They are (a) to test whether the value/glamour effect exists in Australia; and (b) to determine the variable(s) that best identifies value/glamour firms and predicts equity returns. Our findings can be summarised as follows: (a) a strong value/glamour effect exists in Australia; and (b) B/M is the superior proxy for value/glamour.

The implications of this type of study for the practice of investment analysis are important as value and glamour strategies are widely used by investment managers. The significance of the $\mathrm{B} / \mathrm{M}$ variable suggests that it provides a good stock selection tool when forming investment strategies based on value and glamour in Australia. Our findings also support the widely used Fama and French (1993) model as B/M emerges as the best value/glamour proxy. 


\section{References}

Athanassakos, G., 2007, Value vs. glamour stock returns and the value premium: errors in expectations or risk differences? Working paper, The University of Western Ontario.

Banz, R.W., 1981, The relationship between return and market value of common stocks. Journal of Financial Economics 9, 3-18.

Barbee, W. C., Mukherji, S., and G. Raines, 1996, Do sales-price and debt-equity explain stock returns better than book-market and firm size? Financial Analysts Journal 52, 56-60.

Bhandari, L.C., 1988, Debt/Equity ratio and expected common stock returns: Empirical evidence. Journal of Finance 43, 507-528.

Black, F., 1993, Beta and return. Journal of Portfolio Management 20, 8-18.

Brandes, C.H., 2006, Value vs. glamour: updated and expanded, The Brandes Institute.

Brown, P., Keim, D., Kleidon, A., and T. Marsh, 1983, Stock returns, seasonalities, and the taxloss selling hypothesis: Analysis and arguments of the Australian evidence. Journal of Financial Economics 12, 33-56.

Cai, J., 1997, Glamour and value strategies on the Tokyo stock exchange, Journal of Business Finance and Accounting 24, 1291-1310.

Campbell, J.Y., and M. Yogo, 2006, Efficient tests of stock return predictability, Journal of Financial Economics 81, 27-60.

Chan, H.W.H., and R.W. Faff, 2003, An investigation into the role of liquidity in asset pricing: Australian evidence. Pacific-Basin Finance Journal 11, 555-572.

Chan, L.K., Hamao, Y., and J. Lakonishok, 1991, Fundamentals and stock returns in Japan. Journal of Finance 46, 1739-1789.

Dichev, I.D., 1998, Is the risk of bankruptcy a systematic risk? Journal of Finance 53, 11311147.

Fama, E.F., and K.R. French, 1992, The cross-section of expected stock returns. Journal of Finance 47, 427-465.

Fama, E.F., and K.R. French, 1993, Common risk factors in the returns on stocks and bonds. Journal of Financial Economics 33, 3-56.

Fama, E.F., and K.R. French, 1996, Multifactor explanations of asset pricing anomalies, Journal of Finance 51, 55-84.

Fama, E.F., and K.R. French, 1998, Value versus growth: The international evidence. Journal of Finance 53, 1975-2000.

Fama, E.F., and J. MacBeth, 1973, Risk, return, and equilibrium: Empirical tests. Journal of Political Economy 81, 607-636. 
Gaunt, C., 2004, Size and book to market effects and the Fama French three factor asset pricing model: Evidence from the Australian share market. Accounting and Finance 44, 27-44.

Gharghori, P., Chan, H.W.H. and R.W. Faff, 2006, Factors or characteristics? That is the question. Pacific Accounting Review 18, 21-46.

Gharghori, P., Chan, H.W.H. and R.W. Faff, 2007, Are the Fama-French factors proxying default risk? Australian Journal of Management 32, 223-249.

Gharghori, P., Chan, H.W.H. and R.W. Faff, 2009, Default risk and equity returns: Australian evidence. Forthcoming Pacific-Basin Finance Journal.

Graham, B., and D. Dodd, 1934, Security analysis, McGraw-Hill, New York.

Halliwell, J., Heaney, J., and J. Sawicki, 1999, Size and book to market effects in Australian share markets: A time-series analysis. Accounting Research Journal 12, 122-137.

Jaffe, J., Keim, D., and R. Westerfield, 1989, Earnings yields, market values and stock returns. Journal of Finance 44, 135-148.

Kothari, S.P., Shanken, J., and R. Sloan, 1995, Another look at the cross-section of expected stock returns. Journal of Finance 50, 185-224.

Lakonishok, J., Shleifer, A., and R.W. Vishny, 1994, Contrarian investment, extrapolation and risk. Journal of Finance 49, 1541-1578.

Lamont, O., 1998, Earnings and expected returns, Journal of Finance 53, 1563-1587.

La Porta, R., 1996, Expectations and the cross-section of stock returns. Journal of Finance 51, 1715-1742.

La Porta, R., Lakonishok, J., Shleifer, A., and R. Vishny, 1997, Good news for value stocks: further evidence on market efficiency. Journal of Finance 52, 859-874.

Leledakis, G. and I. Davidson, 2001, Are two factors enough? The UK evidence. Financial Analysts Journal 57, 96-105.

MacKinlay, A. C., 1995, Multifactor models do not explain deviations from CAPM. Journal of Financial Economics 38, 3-28.

White, H., 1980, A heteroskedasticity consistent covariance matrix and a direct test for heteroskedasticity. Econometrica 48, 817-838. 
Table 1

Returns and firm characteristics for portfolios formed using rankings on each of the variables

\begin{tabular}{|c|c|c|c|c|c|c|c|c|c|c|}
\hline \multicolumn{11}{|c|}{ Panel A: B/M } \\
\hline & D1 & D2 & D3 & D4 & D5 & D6 & D7 & D8 & D9 & D10 \\
\hline Returns & 0.96 & 1.19 & 1.01 & 1.15 & 1.27 & 1.50 & 1.35 & 1.86 & 2.35 & 3.75 \\
\hline $\mathrm{B} / \mathrm{M}$ & 0.082 & 0.206 & 0.318 & 0.430 & 0.556 & 0.700 & 0.871 & 1.084 & 1.419 & 3.598 \\
\hline$S / P$ & 0.605 & 0.638 & 0.884 & 1.013 & 1.143 & 1.221 & 1.218 & 1.290 & 1.598 & 3.157 \\
\hline$D / E$ & 0.355 & 0.369 & 0.585 & 0.771 & 0.908 & 0.894 & 0.850 & 0.917 & 1.079 & 3.650 \\
\hline SIZE & 410.8 & 709.2 & 1058.3 & 888.1 & 710.8 & 545.5 & 400.7 & 239.9 & 110.3 & 58.5 \\
\hline$E / P$ & -0.057 & -0.057 & -0.040 & -0.028 & -0.031 & -0.024 & -0.035 & -0.040 & -0.070 & -0.174 \\
\hline $\mathrm{C} / \mathrm{P}$ & -0.020 & -0.013 & 0.004 & 0.020 & 0.022 & 0.029 & 0.011 & 0.015 & 0.006 & 0.067 \\
\hline
\end{tabular}

\begin{tabular}{|c|c|c|c|c|c|c|c|c|c|c|}
\hline \multicolumn{11}{|c|}{ Panel B: S/P } \\
\hline & D1 & D2 & D3 & D4 & D5 & D6 & D7 & D8 & D9 & D10 \\
\hline Returns & 0.51 & 1.04 & 0.96 & 0.92 & 1.19 & 1.45 & 1.38 & 1.50 & 1.63 & 2.74 \\
\hline $\mathrm{B} / \mathrm{M}$ & 0.772 & 0.815 & 0.744 & 0.677 & 0.705 & 0.760 & 0.819 & 0.981 & 1.061 & 1.987 \\
\hline $\mathrm{S} / \mathrm{P}$ & 0.016 & 0.071 & 0.161 & 0.301 & 0.500 & 0.797 & 1.196 & 1.787 & 3.050 & 9.395 \\
\hline $\mathrm{D} / \mathrm{E}$ & 0.379 & 0.320 & 0.888 & 1.293 & 0.831 & 0.757 & 0.927 & 1.257 & 1.657 & 4.643 \\
\hline SIZE & 133.4 & 462.3 & 1464.8 & 883.0 & 1069.0 & 1141.0 & 714.3 & 463.0 & 345.6 & 68.5 \\
\hline$E / P$ & -0.090 & -0.056 & -0.041 & -0.032 & -0.016 & -0.002 & 0.013 & 0.024 & 0.005 & -0.124 \\
\hline $\mathrm{C} / \mathrm{P}$ & -0.058 & -0.024 & -0.004 & 0.012 & 0.038 & 0.043 & 0.075 & 0.089 & 0.115 & 0.209 \\
\hline
\end{tabular}

\begin{tabular}{|c|c|c|c|c|c|c|c|c|c|c|}
\hline \multicolumn{11}{|c|}{ Panel C: D/E } \\
\hline & D1 & $\mathrm{D} 2$ & D3 & D4 & D5 & D6 & D7 & D8 & D9 & D10 \\
\hline Returns & 1.26 & 1.40 & 2.02 & 1.34 & 1.45 & 1.44 & 1.49 & 1.50 & 1.72 & 2.62 \\
\hline B/M & 0.582 & 0.738 & 0.812 & 0.731 & 0.691 & 0.723 & 0.760 & 0.864 & 1.071 & 2.290 \\
\hline $\mathrm{S} / \mathrm{P}$ & 0.038 & 0.039 & 0.106 & 0.244 & 0.466 & 0.750 & 1.112 & 1.666 & 2.782 & 5.573 \\
\hline $\mathrm{D} / \mathrm{E}$ & 0.009 & 0.031 & 0.069 & 0.135 & 0.234 & 0.363 & 0.545 & 0.829 & 1.406 & 6.756 \\
\hline SIZE & 44.2 & 79.3 & 140.8 & 294.7 & 463.1 & 669.2 & 844.0 & 887.2 & 449.2 & 1261.3 \\
\hline$E / P$ & -0.083 & -0.104 & -0.096 & -0.067 & -0.045 & -0.024 & -0.017 & -0.010 & -0.019 & -0.091 \\
\hline $\mathrm{C} / \mathrm{P}$ & -0.059 & -0.077 & -0.066 & -0.030 & 0.001 & 0.042 & 0.047 & 0.057 & 0.080 & 0.146 \\
\hline
\end{tabular}

\begin{tabular}{lrrrrrrrrrr}
\hline \multicolumn{1}{l}{ Panel D: SIZE } & \multicolumn{1}{c}{ D1 } & D2 & D3 & D4 & D5 & D6 & D7 & D8 & D9 & D10 \\
\hline Returns & 6.78 & 2.24 & 0.65 & 0.90 & 0.54 & 0.85 & 0.72 & 1.00 & 1.17 & 1.10 \\
B/M & 2.142 & 1.209 & 0.920 & 0.860 & 0.816 & 0.783 & 0.694 & 0.682 & 0.629 & 0.527 \\
S/P & 2.040 & 1.254 & 1.332 & 1.323 & 1.468 & 1.373 & 1.224 & 1.054 & 0.911 & 0.792 \\
D/E & 2.402 & 0.910 & 0.771 & 0.768 & 0.827 & 0.856 & 0.744 & 0.783 & 0.882 & 1.429 \\
SIZE & 2.3 & 4.8 & 8.0 & 12.8 & 20.8 & 35.1 & 65.5 & 141.6 & 404.2 & 4438.5 \\
E/P & -0.349 & -0.205 & -0.128 & -0.065 & -0.028 & 0.011 & 0.036 & 0.055 & 0.058 & 0.057 \\
C/P & -0.093 & -0.101 & -0.041 & -0.020 & 0.009 & 0.046 & 0.066 & 0.087 & 0.091 & 0.097 \\
\hline
\end{tabular}


Table 1 (continued)

\begin{tabular}{lrrrrrrrrrr}
\hline \multicolumn{1}{l}{\begin{tabular}{l} 
Panel E: E/P \\
\hline E/P-
\end{tabular}} & Q1 & Q2 & Q3 & Q4 & Q5 & & & & \\
\hline E/P+ & & & & & & Q1 & Q2 & Q3 & Q4 & Q5 \\
\hline Returns & 3.57 & 2.02 & 1.53 & 0.98 & 0.46 & 0.89 & 1.18 & 1.24 & 1.60 & 2.67 \\
B/M & 1.549 & 0.947 & 0.813 & 0.704 & 0.588 & 0.623 & 0.615 & 0.689 & 0.827 & 1.859 \\
S/P & 2.396 & 0.720 & 0.404 & 0.372 & 0.403 & 0.820 & 1.035 & 1.290 & 1.827 & 3.032 \\
D/E & 2.279 & 0.629 & 0.393 & 0.314 & 0.290 & 0.590 & 0.708 & 1.104 & 1.216 & 2.537 \\
SIZE & 13.9 & 28.4 & 42.4 & 53.9 & 150.1 & 748.0 & 1251.8 & 1210.7 & 807.5 & 409.0 \\
E/P & -0.874 & -0.212 & -0.105 & -0.052 & -0.016 & 0.021 & 0.049 & 0.070 & 0.095 & 0.280 \\
C/P & -0.334 & -0.138 & -0.080 & -0.036 & -0.008 & 0.040 & 0.073 & 0.095 & 0.132 & 0.266 \\
\hline
\end{tabular}

\begin{tabular}{|c|c|c|c|c|c|c|c|c|c|c|}
\hline \multicolumn{11}{|c|}{ Panel F: C/P } \\
\hline $\mathrm{C} / \mathrm{P}_{-}$ & Q1 & Q2 & Q3 & Q4 & Q5 & & & & & \\
\hline $\mathrm{C} / \mathrm{P}_{+}$ & & & & & & Q1 & Q2 & Q3 & Q4 & Q5 \\
\hline Returns & 3.32 & 2.20 & 1.19 & 1.08 & 0.94 & 0.99 & 1.18 & 1.19 & 1.71 & 2.71 \\
\hline $\mathrm{B} / \mathrm{M}$ & 1.386 & 0.923 & 0.791 & 0.664 & 0.589 & 0.669 & 0.655 & 0.679 & 0.827 & 1.977 \\
\hline$S / P$ & 1.670 & 0.618 & 0.502 & 0.403 & 0.400 & 0.721 & 0.877 & 1.235 & 1.815 & 3.926 \\
\hline $\mathrm{D} / \mathrm{E}$ & 1.682 & 0.468 & 0.392 & 0.301 & 0.271 & 0.532 & 0.759 & 0.901 & 1.214 & 3.327 \\
\hline SIZE & 39.2 & 35.3 & 78.4 & 77.7 & 139.9 & 639.8 & 1110.8 & 1060.1 & 1054.8 & 503.0 \\
\hline$E / P$ & -0.571 & -0.183 & -0.113 & -0.065 & -0.025 & 0.013 & 0.043 & 0.057 & 0.065 & 0.115 \\
\hline $\mathrm{C} / \mathrm{P}$ & -0.675 & -0.167 & -0.086 & -0.042 & -0.013 & 0.023 & 0.062 & 0.098 & 0.157 & 0.581 \\
\hline
\end{tabular}

This table reports monthly returns and average firm characteristics for portfolios formed using rankings on each of the six variables. Each month, from January 1993 to December 2004, the equally-weighted (next month) return and firm characteristics are calculated for each portfolio. The returns and firm characteristics reported in the table are the time-series average of the monthly portfolio returns (in percent) and the monthly firm characteristics. (Firm) size is reported in billions of dollars. Panels A, B, C and D present the monthly returns and firm characteristics on decile portfolios formed using rankings on $B / M, S / P$, $D / E$ and size, respectively. Panels $E$ and $F$ present the monthly returns and firm characteristics on quintile portfolios formed using rankings on E/P+, E/P-, C/P+ and C/P-. D1 is the lowest decile portfolio and D10 is the highest decile portfolio. Similarly, Q1 is the lowest quintile portfolio and Q5 is the highest quintile portfolio. 
Table 2

Correlation matrix for the firm characteristics

\begin{tabular}{|c|c|c|c|c|c|c|c|c|}
\hline \multicolumn{9}{|c|}{ Panel A: Full sample } \\
\hline & $\mathrm{B} / \mathrm{M}$ & $\mathrm{S} / \mathrm{P}$ & $E / P+$ & $E / P$ & $\mathrm{C} / \mathrm{P}_{+}$ & $\mathrm{C} / \mathrm{P}_{-}$ & $D / E$ & SIZE \\
\hline $\mathrm{B} / \mathrm{M}$ & 1.000 & & & & & & & \\
\hline$S / P$ & 0.115 & 1.000 & & & & & & \\
\hline$E / P+$ & 0.146 & 0.508 & 1.000 & & & & & \\
\hline $\mathrm{E} / \mathrm{P}$ & $-0.016^{\#}$ & 0.402 & $0.843^{\wedge}$ & 1.000 & & & & \\
\hline $\mathrm{C} / \mathrm{P}+$ & 0.137 & 0.551 & 0.644 & 0.588 & 1.000 & & & \\
\hline C/P- & $-0.016^{\#}$ & 0.414 & 0.579 & 0.686 & $0.847^{\wedge}$ & 1.000 & & \\
\hline $\mathrm{D} / \mathrm{E}$ & 0.256 & 0.716 & 0.458 & 0.311 & 0.505 & 0.321 & 1.000 & \\
\hline SIZE & -0.231 & 0.222 & 0.410 & 0.584 & 0.391 & 0.540 & 0.177 & 1.000 \\
\hline
\end{tabular}

\begin{tabular}{|c|c|c|c|c|c|c|c|c|}
\hline \multicolumn{9}{|c|}{ Panel B: Positive E/P } \\
\hline & $\mathrm{B} / \mathrm{M}$ & $\mathrm{S} / \mathrm{P}$ & $E / P_{+}$ & E/P- & $\mathrm{C} / \mathrm{P}+$ & $\mathrm{C} / \mathrm{P}$ & $D / E$ & SIZE \\
\hline $\mathrm{B} / \mathrm{M}$ & 1.000 & & & & & & & \\
\hline $\mathrm{S} / \mathrm{P}$ & 0.056 & 1.000 & & & & & & \\
\hline$E / P_{+}$ & 0.339 & 0.335 & 1.000 & & & & & \\
\hline E/P- & - & - & - & - & & & & \\
\hline $\mathrm{C} / \mathrm{P}+$ & 0.160 & 0.369 & 0.389 & - & 1.000 & & & \\
\hline $\mathrm{C} / \mathrm{P}-$ & -0.087 & 0.068 & 0.024 & - & $0.611^{\wedge}$ & 1.000 & & \\
\hline$D / E$ & 0.246 & 0.596 & 0.372 & - & 0.356 & $-0.001^{\#}$ & 1.000 & \\
\hline SIZE & -0.308 & -0.159 & -0.223 & - & $0.005^{\#}$ & 0.258 & -0.065 & 1.000 \\
\hline
\end{tabular}

\begin{tabular}{|c|c|c|c|c|c|c|c|c|}
\hline \multicolumn{9}{|c|}{ Panel C: Negative E/P } \\
\hline & $\mathrm{B} / \mathrm{M}$ & $\mathrm{S} / \mathrm{P}$ & $\mathrm{E} / \mathrm{P}_{+}$ & $\mathrm{E} / \mathrm{P}-$ & $\mathrm{C} / \mathrm{P}+$ & $\mathrm{C} / \mathrm{P}-$ & $\mathrm{D} / \mathrm{E}$ & SIZE \\
\hline$B / M$ & 1.000 & & & & & & & \\
\hline$S / P$ & 0.131 & 1.000 & & & & & & \\
\hline $\mathrm{E} / \mathrm{P}+$ & - & - & - & & & & & \\
\hline$E / P-$ & -0.271 & -0.197 & - & 1.000 & & & & \\
\hline $\mathrm{C} / \mathrm{P}+$ & 0.155 & 0.424 & - & 0.062 & 1.000 & & & \\
\hline $\mathrm{C} / \mathrm{P}_{-}$ & -0.124 & 0.124 & - & 0.503 & $0.659^{\wedge}$ & 1.000 & & \\
\hline $\mathrm{D} / \mathrm{E}$ & 0.290 & 0.639 & - & -0.306 & 0.380 & $0.008^{\#}$ & 1.000 & \\
\hline SIZE & -0.300 & 0.093 & - & 0.469 & 0.136 & 0.400 & -0.060 & 1.000 \\
\hline
\end{tabular}

This table reports the time-series averages of monthly cross-sectional Spearman rank correlations between all six variables, covering the period January 1993 to December 2004. The variables used to construct the matrix are the variables employed in the regression analysis. Size is the natural logarithm of the firm's market capitalisation. $B / M, S / P$ and $D / E$ are the raw ratios. $E / P+(E / P-)$ is the interaction term for positive (negative) $E / P . C / P+(C / P-)$ is the interaction term for positive (negative) $\mathrm{C} / \mathrm{P}$. Panel A presents the correlations for the full sample. Panel B presents the correlations for the positive E/P sub-sample. Panel $C$ presents the correlations for the negative E/P sub-sample. Indicates an artificial correlation arising from the interaction terms created for E/P and C/P. \# Indicates the correlation is not significant at the one percent level. 
Table 3

Fama-MacBeth regressions of returns on each of the six variables

\begin{tabular}{|c|c|c|c|c|c|c|}
\hline \multicolumn{7}{|c|}{ Panel A: All variables } \\
\hline & Const & Variable & $\mathrm{E} / \mathrm{P}_{+}$ & E/P- & $\mathrm{C} / \mathrm{P}_{+}$ & $\mathrm{C} / \mathrm{P}_{-}$ \\
\hline $\mathrm{B} / \mathrm{M}$ & -0.0041 & 0.0007 & & & & \\
\hline $\mathrm{S} / \mathrm{P}$ & $\begin{array}{c}(-1.03) \\
-0.0029 \\
(-0.70)\end{array}$ & $\begin{array}{c}(4.19) \\
0.0006 \\
(5.87)\end{array}$ & & & & \\
\hline$E / P$ & $\begin{array}{c}-0.0040 \\
(-0.98)\end{array}$ & & $\begin{array}{c}0.0074 \\
(4.00)\end{array}$ & $\begin{array}{c}-0.0071 \\
(-5.74)\end{array}$ & & \\
\hline $\mathrm{C} / \mathrm{P}$ & $\begin{array}{c}-0.0018 \\
(-0.45)\end{array}$ & & & & $\begin{array}{c}0.0038 \\
(6.70)\end{array}$ & $\begin{array}{l}-0.0075 \\
(-10.66)\end{array}$ \\
\hline $\mathrm{D} / \mathrm{E}$ & $\begin{array}{c}-0.0021 \\
(-0.51)\end{array}$ & $\begin{array}{c}0.0007 \\
(9.52)\end{array}$ & & & & \\
\hline SIZE & $\begin{array}{c}-0.0192 \\
(-1.03) \\
\end{array}$ & $\begin{array}{c}0.0010 \\
(1.09) \\
\end{array}$ & & & & \\
\hline
\end{tabular}

\begin{tabular}{ccc}
\hline \multicolumn{3}{c}{ Panel B: Positive E/P } \\
\hline E/P+ & Const & Variable \\
& 0.0066 & 0.0053 \\
$\mathrm{C} / \mathrm{P}+$ & $(2.40)$ & $(3.83)$ \\
& 0.0052 & 0.0037 \\
& $(1.91)$ & $(4.10)$ \\
\hline
\end{tabular}

\begin{tabular}{ccc}
\hline \multicolumn{3}{c}{ Panel C: Negative E/P } \\
\hline & Const & Variable \\
\hline E/P- & -0.0188 & -0.0091 \\
& $(-3.08)$ & $(-9.77)$ \\
C/P- & -0.0178 & -0.0086 \\
& $(-2.91)$ & $(-11.97)$ \\
\hline
\end{tabular}

This table reports average Fama-MacBeth regression estimates using individual firm data for all months of our sample period - January 1993 to December 2004. In each month, a cross-sectional regression is estimated using Ordinary Least Squares adjusted for White's heteroskedasticity-consistent covariance matrix, wherein next month's return is regressed on one of the six independent variables, in turn. The values reported in the table are the average time-series slope estimates, which are obtained using Weighted Least Squares. The monthly slope estimates are weighted by the inverse of their standard error thereby giving more importance to slope estimates that are more precisely estimated. The associated t-statistics are reported in parentheses directly under the relevant mean slope estimate. Panel A presents the output for the full sample. Panel B presents the output for the positive E/P sub-sample. Panel C presents the output for the negative E/P sub-sample. 
Table 4

Fama-MacBeth regressions of returns on the group of variables specified

\begin{tabular}{lccccccccc}
\hline Panel A: Full sample & & & & & & & & \\
\hline & Const & $\mathrm{B} / \mathrm{M}$ & $\mathrm{S} / \mathrm{P}$ & $\mathrm{E} / \mathrm{P}+$ & $\mathrm{E} / \mathrm{P}-$ & $\mathrm{C} / \mathrm{P}+$ & $\mathrm{C} / \mathrm{P}-$ & $\mathrm{D} / \mathrm{E}$ & SIZE \\
\hline B/M, S/P, E/P, C/P & -0.0060 & 0.0014 & 0.0005 & 0.0283 & -0.0003 & 0.0100 & -0.0003 & & \\
& $(-1.45)$ & $(2.04)$ & $(2.14)$ & $(4.59)$ & $(-0.12)$ & $(3.29)$ & $(-0.27)$ & & \\
& & & & & & & & & \\
ALL & -0.0337 & 0.0025 & 0.0006 & 0.0298 & -0.0009 & 0.0107 & -0.0008 & -0.0003 & 0.0013 \\
& $(-1.88)$ & $(3.41)$ & $(2.36)$ & $(5.24)$ & $(-0.41)$ & $(3.44)$ & $(-0.44)$ & $(-0.99)$ & $(1.63)$
\end{tabular}

\begin{tabular}{|c|c|c|c|c|c|c|c|c|c|}
\hline \multicolumn{10}{|l|}{ Panel B: Positive E/P } \\
\hline & Const & $\mathrm{B} / \mathrm{M}$ & $\mathrm{S} / \mathrm{P}$ & $E / P_{+}$ & E/P- & $\mathrm{C} / \mathrm{P}_{+}$ & $\mathrm{C} / \mathrm{P}_{-}$ & $D / E$ & SIZE \\
\hline $\mathrm{B} / \mathrm{M}, \mathrm{S} / \mathrm{P}, \mathrm{E} / \mathrm{P}, \mathrm{C} / \mathrm{P}$ & $\begin{array}{c}0.0049 \\
(1.74)\end{array}$ & $\begin{array}{c}-0.0001 \\
(-0.18)\end{array}$ & $\begin{array}{c}0.0000 \\
(0.21)\end{array}$ & $\begin{array}{c}0.0103 \\
(2.08)\end{array}$ & & $\begin{array}{c}0.0155 \\
(4.08)\end{array}$ & & & \\
\hline ALL & $\begin{array}{c}-0.0074 \\
(-0.61)\end{array}$ & $\begin{array}{c}-0.0001 \\
(-0.20)\end{array}$ & $\begin{array}{c}0.0001 \\
(0.73)\end{array}$ & $\begin{array}{c}0.0084 \\
(1.63)\end{array}$ & & $\begin{array}{c}0.0146 \\
(3.79)\end{array}$ & & $\begin{array}{c}0.0001 \\
(0.25)\end{array}$ & $\begin{array}{c}0.0005 \\
(0.93)\end{array}$ \\
\hline
\end{tabular}

\begin{tabular}{|c|c|c|c|c|c|c|c|c|c|}
\hline \multicolumn{10}{|c|}{ Panel C: Negative E/P } \\
\hline & Const & $\mathrm{B} / \mathrm{M}$ & $\mathrm{S} / \mathrm{P}$ & $\mathrm{E} / \mathrm{P}+$ & $\mathrm{E} / \mathrm{P}-$ & $\mathrm{C} / \mathrm{P}_{+}$ & $\mathrm{C} / \mathrm{P}-$ & $\mathrm{D} / \mathrm{E}$ & SIZE \\
\hline $\mathrm{B} / \mathrm{M}, \mathrm{S} / \mathrm{P}, \mathrm{E} / \mathrm{P}, \mathrm{C} / \mathrm{P}$ & $\begin{array}{l}-0.0250 \\
(-4.03)\end{array}$ & $\begin{array}{c}0.0069 \\
(6.02)\end{array}$ & $\begin{array}{c}0.0003 \\
(0.67)\end{array}$ & & $\begin{array}{c}-0.0020 \\
(-0.98)\end{array}$ & & $\begin{array}{c}-0.0010 \\
(-1.07)\end{array}$ & & \\
\hline ALL & $\begin{array}{c}0.0880 \\
(3.72)\end{array}$ & $\begin{array}{c}0.0060 \\
(5.18)\end{array}$ & $\begin{array}{c}0.0006 \\
(1.43)\end{array}$ & & $\begin{array}{c}-0.0011 \\
(-0.43)\end{array}$ & & $\begin{array}{l}0.0021 \\
(0.75)\end{array}$ & $\begin{array}{c}-0.0004 \\
(-0.54)\end{array}$ & $\begin{array}{c}-0.0066 \\
(-5.43)\end{array}$ \\
\hline
\end{tabular}

This table reports average Fama-MacBeth regression estimates using individual firm data for all months of our sample period - January 1993 to December 2004. In each month, a cross-sectional regression is estimated using Ordinary Least Squares adjusted for White's heteroskedasticity-consistent covariance matrix, wherein next month's return is regressed on the group of variables specified. The values reported in the table are the average time-series slope estimates, which are obtained using Weighted Least Squares. The monthly slope estimates are weighted by the inverse of their standard error thereby giving more importance to slope estimates that are more precisely estimated. The associated t-statistics are reported in parentheses directly under the relevant mean slope estimate. Panel A presents the output for the full sample. Panel B presents the output for the positive E/P sub-sample. Panel C presents the output for the negative E/P subsample. 